\title{
Indigenous Political Representation: Latin America and International Human Rights Law
}

CATHERINE IORNS MAGALLANES

\section{Introduction}

Indigenous peoples claim greater control over and participation in decisionmaking over their lives. A lack of such control and participation has been identified as a significant problem and impediment for achieving indigenous peoples' human rights. As a result, indigenous peoples claim substantive rights to political participation and representation for the group, not just for the individuals within it. Moreover, such participation and representation is not merely in respect of indigenous territories, but within the mainstream state. As control is exercised from the top, they argue that they need to be participating in the decisions at the highest political levels. From the perspective of self-determination, this needs to be a guaranteed feature of the constitutional and political landscape and not one left to the whim of non-indigenous voters. Such participation thus needs to be enshrined in constitutional legislation as guaranteed political representation.

Both democratic theory - primarily designed to protect the rights of individuals - and self-determination theory - designed to protect the group as well as the individuals in it - have come to the same conclusion. Indigenous peoples need a range of measures to ensure their participation in political decision-making. This will need to include some form of guaranteed political representation at the highest levels of mainstream politics and government, at local and national levels, and will need to be addressed as a matter of constitutional or electoral system design and reform. ${ }^{1}$

The need to address this lack of control has been recognized internationally and has resulted in the development of international guidelines and standards for better political representation. Importantly, international law is increasingly recognizing that indigenous peoples require some form of guaranteed political representation and power of decision-making as a human rights concern. Further, for indigenous peoples to realize their human right to participation in decision-making, states need to take special measures in order to achieve it. ${ }^{2}$

However, the more recent developments in respect of indigenous rights do not yet sit easily with existing, more traditional international human rights 
laws on participation in decision-making within states, which revolve around electoral rights. Electoral rights in international law have been interpreted as providing merely procedural guarantees for individual participation in electing the government of a state. Further, the implementation of these international standards has varied in different countries and even regions worldwide. Significantly, group-based claims to political participation and representation have been rejected as discriminatory, including by the European Court of Human Rights. In contrast, however, the position taken in Latin America recognizes such substantive, group-based rights, including political participation and representation.

In this paper, I first outline the traditional approach to rights of electoral participation within international law, offering some examples from the European Court of Human Rights to illustrate this position. I then discuss the indigenous rights approach, and show how this is the approach adopted in Latin America. I discuss the example of the YATAMA ${ }^{3}$ decision from the Inter-American Court of Human Rights in order to illustrate this.

The paper concludes that the Latin American approach best integrates human rights concerning both electoral participation and indigenous peoples. It therefore provides the best example currently available for re-conceiving the existing principles of international law to better integrate indigenous rights more generally across the body of human rights law and, thus, to better provide for indigenous representation within domestic representative political bodies.

\section{International law on electoral participation and representation}

The traditional approach toward political representation in international law is based on the liberal, individualistic Western concept of democracy. If we look at the development of international law since the creation of the United Nations, initially Western governments deliberately resisted the idea of a right to democracy in international human rights law. Their fear was that the term would become meaningless due to the wide range of different forms of government among states. ${ }^{4}$ Indeed, liberal democracy as we now understand it was then still a relatively recent adaptation..$^{5}$ As a result, the early human rights instruments which were adopted refer to principles and procedural elements, but do not specify any particular type of system within which they must operate.

Over the next 20 years, and particularly during the decolonization era and the focus on self-determination of peoples, ${ }^{6}$ the practice became to encourage liberal, Western-style democracy, with the holding of free and fair elections. ${ }^{7}$ The self-determination of a people was beginning to be associated with the political participation of the individuals within it. While agreement on its 
details was again not universal, there was enough agreement among states to adopt as the foundation for modern electoral rights, Article 25 of the 1966 International Covenant on Civil and Political Rights:

Every citizen shall have the right and the opportunity, without any of the distinctions mentioned in article $2^{8}$ and without unreasonable restrictions:

(a) To take part in the conduct of public affairs, directly or through freely chosen representatives;

(b) To vote and to be elected at genuine periodic elections which shall be by universal and equal suffrage and shall be held by secret ballot, guaranteeing the free expression of the will of the electors;

(c) To have access, on general terms of equality, to public service in his country. ${ }^{9}$

The development of international human rights standards for modern electoral rights was thus based on the simple ideas of free and fair elections, with equal and universal suffrage. No substantive preference is made for any particular electoral system under these rights. Instead, democracy is understood solely in terms of these processes..$^{10}$

The representation of minorities in public life - and their possible exclusion from it as a result of different political systems - has been considered many times by political and human rights theorists as well as by practitioners and those involved in implementing such systems. It was explicitly considered during the drafting of what became Article 25 of the International Covenant on Civil and Political Rights. However, any direction in the Covenant which might have resulted in suggesting particular electoral systems to better represent minorities was explicitly rejected. Instead, the enhancement of electoral participation by minority groups was considered to be a matter for internal state affairs. ${ }^{11}$

The rush to democracy as a result of the break up of Eastern Europe led to suggestions that there is now an international legal right to Western-style, liberal democracy; this right entailed: ${ }^{12}$

- that elections be held at periodic intervals

- freely available and non-discriminatory candidature for office

- party pluralism

- that neither parties nor candidates can be rejected based on ideology or other discriminating norms

- access to the mass media for opposition parties on a non-discriminatory basis

- secret ballots (even in states with high percentages of illiterate voters)

- universal suffrage 
- voters to have freedom to choose between candidates

- votes to be fairly counted.

It is notable that the content of the right as described above addresses only aspects of the conduct of elections for government. There is no standard or requirement as to the type of electoral system to be adopted, or the constitutional protections for minorities..$^{13}$ Thus, under this right it is theoretically and legally possible to have a democracy where free and fair elections take place, but where other civil rights are not protected fully. ${ }^{14}$ It is claimed, instead, that democracy is a 'master right' - at the top of the human rights pyramid.${ }^{15}$ Like self-determination, it is supposedly a prerequisite for other human rights being protected. ${ }^{16}$

In relation to the representation of minorities, the individualistic nature of representation has been stressed in discussion of the international standards, as well as the importance of equality and non-discrimination. Simple majority electoral systems are not considered per se discriminatory. ${ }^{17}$ Instead, the fact that a minority interest might be overridden by the majority, consistently and over time, is a necessary result of a democracy.

This view of electoral rights has been enforced by United Nations Treaty bodies, applied by international election assistance teams, and adopted by states and some regional bodies. ${ }^{18}$ Where indigenous peoples have been underrepresented in decision-making positions within states or in political participation generally, this has been discussed and treated as a matter of discrimination..$^{19}$ It has not been suggested that there is any substantive right to participation which is any different from that of any other citizen, or that remedies might lie within the design of electoral systems and methods of representation.

In contrast, for example, many democratic theorists have suggested that the position of minorities within states needs to be taken special account of in the design of an electoral system. Instead of merely formal equality, substantive equality should be achieved. The argument is that there should be group or collective rights, not just individual rights of participation. For example, power-sharing arrangements may be explicitly built in and/or some measures adopted in order to better ensure that a minority is represented in a national parliament. Such measures may merely take the form of the adoption of a proportional representation system, which is more likely to result in a minority-based political party winning seats in parliament. Where a minority is territorially concentrated, then autonomy measures and singlemember national districts may be most appropriate. ${ }^{20}$ Or a system might go so far as to guarantee that a particular position - such as a parliamentary seat - is filled by a member of a particular minority. ${ }^{21}$ The precise method chosen will depend on the political and social situation in the country 
concerned. But the key feature is that an aim is substantive equality between groups and not merely formal equality between citizens.

In line with such arguments, increased concern for adequate minority political participation and representation has been shown within some regional organizations. There has been more of a focus on effective, informed participation in public life, including participation by minorities in public discussions. Much of it is still expressed largely in terms of individual 'persons belonging to minority groups, ${ }^{22}$ but there is also developing concern for group representation, in order to better fulfil the idea of public life consisting of discussion between relevant actors.

However, the traditional international law on electoral rights is still focused on individuals and procedures. It does not adopt the more substantive recommendations of the political theorists and even suggests that schemes based on collective group rights may be contrary to human rights law. Such interpretations of the law have accordingly been adopted in most domestic and regional human rights systems. It is significant that this interpretation has been adopted by the European Court of Human Rights, as this court is well-established and its decisions are regarded highly.

Two recent decisions of the European Court of Human Rights illustrate this more traditional approach to electoral representation. In 2008, in respect of Kurdish representation in Turkey, the European Court of Human Rights upheld a system which effectively denied Kurdish representation due to an extremely high threshold requirement. ${ }^{23}$ Despite it being suggested that the high national vote threshold was actually a design feature, deliberately adopted in order to effect the denial of Kurdish representation, formal individual equality was applied and it was held that there was no discrimination inherent in the electoral system as such.

In a decision of December 2009, the court went even further and actually rejected the power sharing arrangement adopted in Bosnia and Herzegovina as being contrary to the European Convention on Human Rights. ${ }^{24}$ There, while the lower parliamentary assembly was open to individual candidates without regard to minority affiliation, the Bosnian constitution explicitly allocated the seats in the upper House to persons belonging to one of the three main minority groups: Bosniacs, Croats and Serbs. ${ }^{25}$ Further, the presidency was also a collective of three persons, one from each of these groups. ${ }^{26}$ There was also minority interest veto and a veto provision for the upper House. This system was deliberately designed to restore peace by sharing power between the previously-warring factions and prevent interethnic conflict in the future. The Court thus agreed that the system had a legitimate purpose and was justified at the time it was devised. However, the Court held that it discriminated against persons who did not affiliate with 
one of these three minorities (such as Romas and Jews). ${ }^{27}$ Because peace had now been established - that is, through the proper functioning of the system - such discrimination was said to be no longer justified. Overall, the court held that it was acceptable to have some power-sharing mechanisms between different minority groups in a state, especially where that was necessary in order to keep the peace..$^{28}$ However, this was not allowed to be maintained if it excluded some parties on the basis of ethnicity. Instead, a different mechanism had to be chosen.

While the particular power-sharing measures being examined in this case may seem extreme, in that the power sharing completely excluded some groups from participation at a particular level, it was not thought unusual or extreme when it was devised. Indeed, based on the previous jurisprudence of the European Court of Human Rights as well as other European guidelines for state practice in this area, it could reasonably have been expected that it was legally allowable under the Convention. ${ }^{29}$ However, the European Court suggested that all measures which assign seats or other elements of decision-making on the basis of ethnicity discriminate against people who are not members of those groups.

Some legal commentators have argued that, under these interpretations, guaranteed parliamentary seats for indigenous peoples would therefore be contrary to international human rights law. ${ }^{30}$ This is an interesting implication, given that this particular measure has been adopted in various countries worldwide in respect of indigenous peoples - such as New Zealand, Taiwan, Columbia, Venezuela, Burundi and Rwanda - indeed, it has also been used in various countries to ensure representation of other groups, such as women.

\section{The indigenous rights approach}

Indigenous peoples have argued that the traditional, individualistic approach to human rights has not adequately protected their cultures or existence as peoples. They have argued for recognition of a group right to selfdetermination and thus greater control over and participation in decisionmaking over their lives. As a means of achieving this, they have claimed rights to a variety of methods of participation, from better participation within the mainstream state processes (including guaranteed representation, as well as consultation and consent over decisions that concern them) to complete authority or self-government by the group over autonomous indigenous territories.

There is a lot of support within democratic governance theory for the indigenous claims made. For example, there is support for autonomous self-government in indigenous territories, guaranteed representation within 
mainstream government (at national, regional and local levels), and consent to (that is, veto over) matters particularly concerning them. The aim is power sharing at national, regional and local levels through indigenous political participation, by the individual and the group.

There are two reasons given for the choice of these devices. The first is instrumental: only through such high-level political participation in decisions that concern them, it is argued, will indigenous rights be protected - both the traditional, liberal, individualistic human rights and the more contentious modern concepts of group rights. The second reason focuses more on the group than the individual: that a key aspect of indigenous self-determination is self-government. For most indigenous peoples, self-determination will be exercised through self-government within the states in which they live rather than through secession and formation of an independent indigenous state. So, discussion has turned to how to achieve self-determination through self-government within the modern democratic state.

Importantly, international human rights law is recognizing these indigenous claims and has recently endorsed them with the adoption of the United Nations Declaration on the Rights of Indigenous Peoples. ${ }^{31}$ The Declaration reflects the substantive approaches taken by democratic theorists towards minority group participation within government. It recognizes the right of indigenous peoples to effective participation in decision-making and that the group right, including that of self-determination, provides the basis for individual participation. It upholds a right of indigenous autonomy or self-government in matters relating to their internal and local affairs, to maintain and strengthen their own institutions, while still retaining the right to participate fully in the life of the state. Such rights are thus not merely procedural but substantive and results-focused.

It has been suggested that the rights expressed in the Declaration also recognize that indigenous peoples have the right to negotiate for and achieve a new constitutional framework which would better achieve all of these aspects of political participation in representation. This has been called 'belated State building' - that is, redesigning the state in order to redraw the boundaries of power between indigenous peoples and the other groups within it. ${ }^{32}$ In addition to this 2007 Declaration, United Nations Treaty bodies have applied other aspects of international human rights law to require better participation of indigenous peoples in decision-making fora, including an emphasis on the right of the group rather than just on individuals. ${ }^{33}$

I have identified more fully elsewhere that this newer approach to indigenous rights is not yet integrated with the international law concerning electoral rights. ${ }^{34}$ There thus exists contrasting standards within international human rights law: that concerning electoral rights, with its individualistic and procedural focus, and that concerning indigenous rights to substantive, 
group-based political participation and representation. It is these contrasting standards which states and other decision-makers must implement and apply to the situations before them. And it is with these contrasts in mind that I now turn to Latin America, to identify what choices have been made there relating to the standards to uphold with respect to indigenous participation.

\section{The Latin American approach}

The Latin American approach to the political participation of minority groups has differed from the European approach and is more in line with the approach to indigenous rights under international law. In Latin America, the 1969 American Convention on Human Rights contains a right to participation in government (Article 23) which is almost identical to Article 25 of the International Covenant, as well as almost identical to the equivalent right in the European Convention. The Convention recognizes only individual rights, not group rights; and, as we have seen, in Europe and international law generally, this particular provision has been interpreted to have an individualistic and procedural focus. Yet, despite this, both the Inter-American Commission on Human Rights and the Inter-American Court of Human Rights have, pursuant to this right, managed to uphold indigenous rights to participation which have their basis in the group, not just individuals.

First, it is important to note that some Latin American countries have already undertaken belated State-building-type exercises and amended their constitutions in order to better provide for indigenous self-government and/ or political representation. This has included establishing autonomous selfgovernment regions, such as in Nicaragua, as well as reserved or guaranteed parliamentary seats for indigenous representatives, such as in Colombia and Venezuela. Importantly, the indigenous representatives in these countries may be chosen through traditional indigenous decision-making procedures, such that selection is not based solely on liberal, Western-style democratic processes.

The most significant recent interpretation of these political rights is the 2005 case of YATAMA v Nicaragua. This case considered Nicaragua's electoral law in the largely indigenous autonomous regions of the Atlantic Coast. These autonomous regions were the result of a re-design of the political order within the state, recommended by the Inter-American Commission in $1983,{ }^{35}$ carried out with the full participation of the indigenous peoples, and established in $1987 .{ }^{36}$ The result included the right of the indigenous inhabitants to live and administer their own affairs according to their traditions and to elect and be elected as authorities of the regions. ${ }^{37}$ Unfortunately, the Nicaraguan government has twice been found to have 
violated the rights of the indigenous peoples within these regions, once in relation to their electoral rights. ${ }^{38}$

At issue in the YATAMA decision were the state electoral laws: these laws required all candidates to be members of political parties, required each party to have fielded candidates in $80 \%$ of the municipal electorates in the district, and required the individuals to have been elected according to prescribed procedures. ${ }^{39}$ YATAMA was an indigenous organization which chose its candidates through traditional, indigenous, community-based mechanisms. ${ }^{40}$ It became a political party in order to field candidates for the elections to the authorities governing the regions, and was said to be "the principal indigenous political organization in the country. ${ }^{41}$ However, it did not field candidates in $80 \%$ of the electorates of the autonomous regions because some of these electorates were dominated by voters from other ethnic groups. ${ }^{42}$ These electorates did not have the support for an indigenous candidate, nor the cultural connection for community selection. However, the Supreme Electoral Council prevented YATAMA from presenting candidates for election, ostensibly for not meeting the electoral law requirements. The result was 'an abstention rate of approximately $80 \%$ ' in the regional elections, largely due to indigenous voters failing to vote, because there were not the chosen indigenous candidates to vote for.

The court in YATAMA held that that the electoral laws in question placed disproportionate restrictions on the rights of political participation of the YATAMA candidates and of the indigenous voters who would have wanted to vote for them. 'The restriction that they had to participate through a political party imposed ... a form of organization alien to their practices, customs and traditions,' ${ }^{43}$ which was an 'impediment . . . to participate effectively on the conduct of public affairs. ${ }^{44}$ The requirement to field candidates in $80 \%$ of the region's electorates 'did not take into account that the indigenous and ethnic population is a minority.' ${ }^{45}$ The court ordered that the government ensure indigenous access to the political system and that they be integrated into the governmental institutions in a direct and proportional manner.

In terms of the international human rights to indigenous electoral participation, the decision is significant in two ways. First, it is based on the indigenous right of autonomous self-government rising from indigenous rights law - that is, including cultural self-determination, land rights, and the application of belated state-building in order to re-design the appropriate relationship between indigenous peoples and the state. The decision explicitly bases itself on these more general rights in the Nicaraguan Constitution and the regional Autonomy Statute, while the provisions recognizing these rights and the Autonomous Regions themselves were a result of such belated state-building. These factors were fundamental to interpreting the right of electoral participation in the regions. 
Second, the decision is squarely based on the right of political participation as expressed in the standard manner of Article 25 of the International Covenant. The court interprets this right in light of the abovementioned indigenous rights, to require more than formal equality of such comparatively standard electoral requirements. It assessed the actual effect of these requirements on indigenous political participation, taking into account their minority status; and the court ordered measures designed to achieve substantive equality. Moreover, the will and cultural preservation of the indigenous communities was considered important, not just that of the individual voters and candidates. Thus it recognized the need to take account of the indigenous group as a whole, plus the suggested methods of taking this into account are in line with the democratic theorists' suggestions for achieving better minority group participation in political life.

It could be argued that the YATAMA decision is peculiar to the specific characteristics of the Nicaraguan situation, as it contains largely indigenous autonomous regions, or even peculiar to Latin America, with the significant indigenous populations there. As such, it would not necessarily represent a useful precedent for other regional or international bodies to adopt in their interpretations of democratic rights. However, I suggest that the decision is not peculiar to Latin America, and that it could be applied to minority political participation generally. For example, it could be applied where the minority is substantively disenfranchised, and even more so where the minority cultural traditions and decision-making are different from those of the majority society. I suggest that the decision in YATAMA rather reflects an increased sensitivity to indigenous rights and a greater willingness to accommodate them in existing human rights law. It is only since the rise of indigenous human rights laws and principles that such restrictions on indigenous political participation have been considered discriminatory, even in Latin America, and especially for the reasons given by the Court in YATAMA.

It is instructive to compare the YATAMA decision with that of the European Court of Human Rights on the electoral regulations restricting the Kurdish political participation, discussed above. ${ }^{46}$ If a more substantive approach had been taken by the European Court in that case - that is, an approach more in line with that taken by the Inter-American Court - then the decision could have been very different. As in YATAMA, it could have recognized that the Kurdish group as a whole required better access to the political system. Given that the Turkish case was decided after the YATAMA case, it was presumably a conscious choice of the European Court to take the more traditional approach that it did, emphasizing formal and individual equality over substantive minority group equality. 


\section{Conclusion}

This paper is based on the claims made by indigenous peoples in respect of self-government and participation in decision-making, and on the support given to these claims from democratic theorists and in international law. The measures for protection of indigenous rights recognized in international law largely match those recommended by political theorists, ranging from consultation on measures affecting indigenous peoples to effective representation in government and even autonomy as a means of selfgovernment. International human rights law does not prescribe how best to achieve these ends or measures, but this will inevitably entail some form of belated state-building within their states, in order to re-draw the boundaries of power within the state.

In contrast, however, the international law on democratic governance is not so accommodating of the group rights or claims emerging in the indigenous rights arena. Democracy has been interpreted as being a liberal set of procedural guarantees for individual participation in electing the government of a state. While group rights to cultural protection have been recognized, they are not well carried over into the field of electoral participation. Applications of the law to particular cases have denied the legality of some group accommodations, even where they match measures suggested by political and legal theorists. Further, cases of arguable substantive discrimination against minority groups have been upheld, often in the name of formal, individual equality. It has been argued that the various cases show that the consociational approaches favoured by theorists and consistent with the indigenous rights are contrary to the international laws on democracy.

The Latin American experience shows that this more traditional, individualistic approach is not a universal interpretation of rights of political participation. It shows that group rights and minority guarantees for indigenous peoples can be upheld, even pursuant to standards worded almost identically to the cases where the same kinds of claims are denied. This thus suggests that it is not as hard a task as it may seem to integrate the indigenous rights standards into existing democratic political participation standards.

Whatever the size of the task, efforts will need to be made at reconceiving the existing principles of political participation in international law if indigenous rights are to be integrated across the body of human rights law. For example, I suggest that elections need to be seen as a means to an end, not as the end in themselves. The appropriate end is self-determination of a people and thus effective participation in decision-making. As such, a substantive interpretation needs to be taken to such rights of participation, 
in law not just in theory. Only with such a conception of democracy will it be able to achieve its claimed status as the master right through which other human rights will be protected. At the moment, it is certainly not sufficient as a master right for indigenous peoples. Indeed, it is not even sufficient for achieving indigenous peoples' full or effective democratic participation, let alone as a means to guarantee their other human rights.

This is not merely an academic exercise about the proper categorization or conception of different human rights laws. It is relevant to the creation and re-design of any electoral system in a country with indigenous peoples within it. For example, it is relevant to the debate within Aotearoa New Zealand over Maori representation in the new Auckland 'supercity' council: which approach one takes towards electoral rights affects whether or not reserved Maori seats are created on this council, and on what basis they are created (for example, individually-elected, Maori roll positions, or the truly group-based, iwi-appointed mana whenua seats). The Royal Commission on Auckland Governance which recommended the creation of reserved Maori seats in 2009 took an approach closer to that of the Inter-American Court. The approach taken by those who have rejected the Royal Commission's recommendations reflect that of the European Court. Recognition that such positions and decisions are reflections of different approaches towards the interpretation of the relevant rights (and of what those approaches are based on) can affect the domestic interpretation and application of such rights.

In conclusion, the emerging indigenous rights of participation in decisionmaking are challenging the international human rights system to re-think some of its fundamental tenets, particularly with respect to the recognition of group rights. This is illustrated well with respect to the existing, more traditional field of political participation rights. The Latin American approach provides a useful example of such recognition. Explicit consideration of these approaches will be particularly relevant to Aotearoa New Zealand as each can produce a dramatically different result for the make-up of our representative political bodies. Importantly, for indigenous peoples, such integration can make a positive difference to peoples' lives through the creation of more effective measures for realizing their full self-determination.

1 See 'The Lund Recommendations on the Effective Participation of National Minorities in Public Life and Explanatory Note', Foundation on Inter-Ethnic Relations, September 1999, ISBN 90-7598905-9.

2 For example, the aim of the group which developed the Lund Recommendations, ibid, was to make recommendations for states in elaborating their obligations under international human rights law. See John Packer, 'The origin and nature of the Lund Recommendations on the Effective Participation of National Minorities in Public Life', Helsinki Monitor (HM), 11 (2000), pp.29-61. 


\section{Indigenous Political Representation}

3 YATAMA v Nicaragua, Series C, No.127, Judgment of 23 June 2005.

4 Susan Marks, The Riddle of All Constitutions, Oxford, 2000, p.32.

5 Jan Knippers Black notes that the nation-state itself 'is itself a fairly recent social construct' and that even '[a]t the turn of the twentieth century . . . there were only nine countries which could legitimately be considered democratic, and by 1960 only twenty-nine.' Further, it was not until the twentieth century that it acquired the various features that we now take for granted as being essential to the concept and definition of a democracy. See 'What kind of democracy does the "democratic entitlement" entail?' in Gregory Fox and Brad Roth, eds, Democratic Governance and International Law, Cambridge, 2000, pp.517-31, p.517.

6 This was pursuant to UNGA Resolution 1514 (XV), the Declaration on the Granting of Independence to Colonial Countries and Peoples (1960 UNYB 44-50) and UNGA Resolution 2625 Declaration on Principles of International Law Concerning Friendly Relations and Cooperation Among States in Accordance with the Charter of the United Nations (9 ILM 1292, 1970). For more information on their application and on the encouragement of democracy, see Fox and Franck, below n 7.

7 See, for example, Gregory Fox, 'The Right to Political Participation in International Law', Yale Journal of International Law (YJIL), 17, 2, 539 (1992), p.539; see also Thomas M. Franck, 'Legitimacy and the Democratic Entitlement', in Fox and Roth, eds, Democratic Governance, pp.25-47, pp.32-33.

8 Article 2 provides that the rights in the ICCPR are to be respected "without distinction of any kind, such as race, colour, sex, language, religion, political or other opinion, national or social origin, property, birth or other status'.

9 International Covenant on Civil and Political Rights, Article (25), GA res. 2200A (XXI), 21 UN GAOR Supp. (No. 16) at 52, UN Doc. A/6316 (1966); 999 UNTS 171; 6 ILM 368 (1967).

10 Fox, 'The right to political participation in international law', in Fox and Roth, eds, Democratic Governance, pp.48-90, p.49.

11 David Wippman, 'Practical and Legal Constraints on Power Sharing', in David Wippman, ed., International Law and Ethnic Conflict, Ithaca, 1998, pp.211-41, p.236.

12 Thomas M. Franck, 'The Emerging Right to Democratic Governance', American Journal of International Law (AJIL), 46 (1992), p.67; Gregory H. Fox, 'Election Monitoring: The International Legal Setting', 19 Wisconsin International Law Journal (WILJ), 295 (2001), pp.299-300. See also Thomas M. Franck, 'The Democratic Entitlement', University of Richmond Law Review (URLR), 29, 1 (1995).

13 Fox, 'Right to Political Participation', p.556, n 72 and accompanying text.

14 Fox, 'Election Monitoring' p.317, quoting Fareed Zakaria, 'The Rise of Illiberal Democracies', Foreign Affairs, Nov/Dec. 1997, p.22.

15 Farer, 'The Human right to participate in Government: Toward an Operational Definition', 82 American Society of International Law Proceedings 505 (1988); as noted in Fox, 'Election Monitoring', n84.

16 For an example of this in the UN context, see the UNCHR Resolution 1999/57, 'Promotion of the Right to Democracy.' Paragraph 1 states 'democracy fosters the full realization of all human rights.' UN Doc. E/CN.4/1999.SR.57 (27 April 1999).

17 Fox, Right to Political Participation, p.564.

18 See, for example, the Human Rights Committee 'General Comment 25: The right to participate in public affairs, voting rights and the right of equal access to public service 


\section{Journal of New Zealand Studies}

(Art. 25)', (Fifty-seventh session, 1996), U.N. Doc. CCPR/C/21/Rev.1/Add.7 (1996), reprinted in Compilation of General Comments and General Recommendations Adopted by Human Rights Treaty Bodies, U.N. Doc. HRI/GEN/1/Rev.6 at 168 (2003). For reviews of the practice of election assistance and monitoring teams, see Fox, YJIL, above n 7; Fox, 2000, above n 10, and Fox, WILJ, above n12.

19 See, for example, the Human Rights Committee, General Comment No.23, 'Rights of minorities (Article 27)', adopted 8 April 1994, reprinted in 'Compilations of General Comments and General Recommendations', p.158, para.7. See also the Committee's Opinions under the Optional Protocol, concerning Article 27, such as Lansman et al $v$ Finland (No 1) Communication No.511/1992, UN Doc CCPR/C/52/D/511/1992, 8 November 1994, at para.9.5. See also Lansman et al v Finland (No 2) Communication No.671/1995, UN Doc CCPR/C/58/D/671/1995, 22 November 1996, at para.10.4. See also Mahuika et al $v$ New Zealand, Communication No.547/1993, UN Doc CCPR/ C/70/D/547/1993, 15 November 2000, at para 9.5.

20 See 'The Lund Recommendations on the Effective Participation of National Minorities in Public Life' (1999), http://www.osce.org/hcnm/documents/recommendations/lund/index .php3, accessed 23 July 2010.

21 Ibid., Recommendation 6.

22 Steven Wheatley, Democracy, Minorities and International Law, Cambridge, 2005, p.131, quoting the Warsaw Declaration: Towards a Community of Democracies, adopted 27 June 2000, 39 ILM (2000) 1306. The Warsaw Declaration stated that informed participation in 'political life, including by persons belonging to minority groups, is fundamental to a vibrant and durable democracy'.

23 Yumak and Sadak v Turkey, Appl.10226/03, Judgment 8 July 2008 [GC].

24 Sejdic and Finci $v$ Bosnia and Herzegovina (appl. nos.27996/06 and 38436/06), Decision of the Grand Chamber on 22 December 2009. http://www.echr.coe.int.

25 Ibid., Article IV, Constitution of Bosnia and Herzegovina, reproduced in para.12 of the decision.

26 Ibid., Article V, Constitution of Bosnia and Herzegovina, reproduced in para.12 of the decision.

27 Ibid., para.50 (concerning the complainants' ineligibility to stand for election to the upper House of Peoples) and para.56 (concerning the complainants' ineligibility to stand for election to the Presidency).

28 Ibid, para.48.

29 For example, the European Court of Human Rights had previously upheld the Belgian law which regulated membership in the Flemish Council according to membership of particular language groups. Mathiue-Mohin and Clerfayt v Belgium, 10 ECHR (series A), 1988.

30 David Wippman, Practical and Legal Constraints, p.237; see also Wheatley, Democracy, Minorities and International Law, p.163.

31 General Assembly 'Resolution 61/295: Declaration on the Rights of Indigenous Peoples', UN Doc A/61/67, Annex (13 September 2007). It was adopted by 143 states in favour, with four votes against (Australia, Canada, New Zealand and the United States) and 11 abstentions. Since then, Australia, New Zealand and Canada have lodged statements in support of the Declaration, and the United States has stated that it is reviewing its position.

32 S. James Anaya, Indigenous Peoples in International Law, New York, 1996, p.130. 


\section{Indigenous Political Representation}

33 See the Human Rights Committee, 'General Comment No.23: The rights of minorities (Art.27)', UN Doc. CCPR/C/21/Rev.1/Add.5, para.6.2 (8 April 1994).

34 See Catherine Iorns Magallanes, 'Indigenous Rights and Democratic Rights in International Law - An "Uncomfortable Fit"?' 15, 1 UCLA Journal of International Law and Foreign Affairs, forthcoming.

35 Inter-American Commission on Human Rights, Report on the Situation of Human Rights of a Segment of the Nicaraguan Population of Miskito Origin and Resolution on the Friendly Settlement Procedure Regarding the Human Rights Situation of a Segment of the Nicaraguan Population of Miskito Origin, OAS Doc. OEA/SER.L/V/II.62, doc.10, rev.3 (1983), OEA/Ser/L/V/II.62, doc.26 (1984) (Case No.7964).

36 Act No.28 of October 30, 1987, entitled 'Statute of Autonomy of the Atlantic Coast Regions of Nicaragua'. Chapter VI of the Nicaraguan Constitution entitled 'Rights of the Atlantic Coast communities' establishes that these communities 'are an indissoluble part of the Nicaraguan people' and have the right 'to preserve and develop their cultural identity within national unity; establish with their own forms of social organization and administer their local affairs in accordance with their traditions'. 1987 Constitution of the Republic of Nicaragua, with the constitutional reforms.

37 Relevant provisions of the Nicaraguan Constitution are Articles 5, 49, 89 and 180. For example, Art. 89: 'the right to preserve and develop their cultural identity within national unity; establish their own forms of social organization and administer local affairs according to their traditions'. Article 180: 'have the right to live and develop under forms of social organization that correspond to their historical and cultural traditions'. See also Article 11(7) Statute of Autonomy of the Atlantic Coast Regions, as described in YATAMA, above n 3, para.205, n 171.

38 In the other case the Court held that the government violated the property rights of one of the indigenous communities, by not recognizing indigenous communal property titles, and granting logging concessions over indigenous lands in the regions. Case of the Mayagna (Sumo) Awas Tingni Community v Nicaragua, Inter-Am. Ct. H.R. Series C, No.79. Judgment of 31 August 2001 (Merits and Reparations).

39 See, for example, YATAMA, above n 5, para.221. For a summary of the electoral law requirements, see M.S. Campbell, 'The Right of Indigenous Peoples to Political Participation and the Case of YATAMA v. Nicaragua', 24 Arizona Journal of International and Comparative Law 499 (2007), at pp.503-5. Available at http://www.ajicl.org /AJICL2007/Campbell_Note.pdf.

40 The candidates were 'chosen directly in assemblies (according to the practices and customs of [the indigenous] communities) to represent the interests of their members'. YATAMA, para. 227.

41 YATAMA, para.228.

42 YАTAMA, paras.221-23.

43 YATAMA, para.218.

44 YATAMA, para.220.

45 YATAMA, para. 223.

46 See n 23 above. 
Journal of New Zealand Studies 